\title{
ELITE-ACTIVIST RELATIONSHIPS IN POLITICAL PARTIES: A SOCIAL EXCHANGE ANALYSIS OF CANADIAN PARTIES
}

\author{
Royce Koop
}

\begin{abstract}
How can we understand interactions and relationships between party elites and activists? We argue that social exchange theory (SET) provides a useful framework to understanding interactions and relationships between party actors. This article develops a SET framework to analyse intra-party relationships and marshals the framework (in addition to interview and observation data) to analyse one set of relationships, those between Canadian Members of Parliament and the party activists in their constituencies.
\end{abstract}

The nature of relationships between elites and rank-and-file activists in political parties is an ongoing theme in the study of party organisations. However, we lack a unified theory of elite-activist relationships within political parties. This article proposes that social exchange theory (SET) provides substantial insight into such relationships, and applies a SET framework to one set of intra-party relationships, those between Canadian Members of Parliament (MPs) and the party activists in their constituencies. SET defines relationships in terms of costbenefit analysis, with the exchange of both material and, crucially, non-material rewards essential to the maintenance of the relationships (see Blau 1964). Conceptualising elite-activist relationships as social exchange relationships elucidates characteristics of intra-party exchange not previously recognised in past studies that rely solely on the use of 'hard' rewards and benefits between actors.

This article is structured in four sections. First, it expands on the tacit exchange framework described above and describes SET in greater detail, with particular attention paid to explaining the advantages that this theory of relationships holds over the present understanding of intra-party relationships. Then, after an overview of the cases and methods employed, the article turns to a brief case study of elite-member relationships. This study draws on interview and observation data related to Canadian MPs to demonstrate how such elites act in accord with the expectations of the SET framework, drawing on their positions to provide benefits to party members in their constituencies in order to maintain their participation in the relationship. The article concludes by proposing explanatory questions generated from this application of SET to elite-member relationships that may be addressed in future studies.

\section{Review}

Accounts of party organisation emphasise the division of functions such as policy formulation (e.g., Katz and Mair 1995: 10-11) and candidate selection (e.g., Bille 2001) between 
leaders and activists, but do not focus on the ongoing push-and-pull relationships between those intra-party actors. However, a broad reading suggests that any such relationship is viewed as a tacit exchange relationship, with two separate literatures outlining (1) the benefits provided to party activists from participating in parties and (2) the benefits of party membership to elites.

The first side of this exchange relationship involves the benefits attained by activists from joining and participating in political parties. The beginning point is the typology of incentives to party membership developed by Clark and Wilson (1961), within which activists are attracted to participation by three incentives. First, purposive incentives motivate activists that agree with the policy goals of the party and are willing to work to see those policies implemented. Second, solidary incentives refer to the social rewards of party activism and the benefits associated with being 'a part of the team'. Third, material incentives are related to patronage and other rewards of associating with party elites. Careerist incentives are related to material incentives. Seyd and Whiteley (1992) expand on this framework, arguing that altruistic motives and social norms must also be taken into account.

Activists therefore receive benefits by joining and participating in parties, but they also provide substantial benefits to parties and thus to party elites. Scarrow (1996) notes seven benefits provided by activists to their parties: (1) large, diverse membership lists provide legitimacy to parties; (2) activists tend to be loyal voters; (3) activists are 'ambassadors to their communities' who are seen to multiply votes through family and business connections; (4) activists tend to contribute funds; (5) activists provide labour benefits; (6) activists provide ideas that may translate to party policy; and, (7) activists are an important source of candidates for public office. Activists' participation in constituency campaigns is viewed as crucially important to the success of these campaigns: several studies employing different methodologies have repeatedly demonstrated the electoral benefits of well-staged constituency campaigns (e.g., Carty and Eagles 2005; Denver et al. 2002). Campaign managers in Canada regularly bemoan the lack of volunteers available to them (e.g., Carty 1991: 167). In addition to these electoral benefits, activists and the local party organisations they occupy provide parties with important linkage benefits (e.g., Clark 2004; Widfeldt 1999).

While the research previously cited (especially by Scarrow) establishes a tacit exchange relationship between party elites and activists, other research in political science either explicitly uses exchange frameworks to explore intra-party relationships and their outcomes or criticises the use of such frameworks. ${ }^{1}$ These pieces provide insight into the development of a SET framework that I subsequently use to explain and account for relationships between party actors.

Strom (1990) provides an important rational choice account of intra-party exchange and the challenges that enlisting labour for partisan tasks provides for party elites. Strom's focus, however, is on hard, tangible benefits that party elites provide activists, particularly policy influence and 'spoils' (pp. 575-6). Exchange frameworks are often used to account for relationships between social democratic parties and labour unions. In a series of articles, Quinn $(2002,2010)$, for example, argues that the relationship between UK Labour and unions is best understood as an exchange relationship, with unions offering votes and funds in exchange for policy concessions. From Quinn's perspective, the crucial question surrounding the Labour-union relationship is the factors underlying the survival or decay of the relationship, and exchange theory provides several clues as to what those factors are. Quinn (2012) also marshals am exchange framework to explain and account for the relationships between the media and 
party spin-doctors, in which parties supply information about policies and gossip to journalists in return for more favourable coverage.

Closely related to exchange approaches are those of Koelble (1996) and Muller (2000), who conceive of leader-activist relationships as principal-agent relationships, with activists as principals contracting out responsibilities to leaders and suffering agency costs as a result. So too is May's Special Law of Curvilinear Disparity, which hypothesises a potential breakdown in elite-activist relationships resulting from divergence in the purposive goals of party elites (who are in pursuit of the median voter) and party 'sub-leaders' who tend to be both ideologically consistent and rigorous (May 1973). The breakdown occurs when subleaders fail to impose their ideological rigour on their parties and as a result deprive elites of valuable labour benefits. Furthermore, the stratarchical organisational arrangements of Katz and Mair's cartel party type (1995: 21) and Carty's franchise party type (2004) specify that local autonomy is a product of exchange: activists bring their labour and in return elites give them a free hand in the localities.

Most importantly, Ware (1992) criticises exchange frameworks as typically applied to political parties, thereby opening up the possibility of improving such frameworks. Ware argues that exchange frameworks have not been particularly important to understanding intraparty relationships, although they may become more important over time. Like Strom, however, Ware has a narrow conception of the goods provided to activists within exchange relationships, with a particular focus on policy and material rewards. Instead, Ware argues that exchange models have neglected rewards that activists receive from their participation, notably 'gifts', solidary rewards and rewards related to loyalty or habit (p. 72).

Ware calls our attention to both the shortcomings as well as the potential of exchange frameworks to usefully account for intra-party relationships between elites and activists. The use of SET allows us to address Ware's criticism by allowing for the inclusion of 'soft' rewards for activists within the wider exchange framework.

While SET derives from and shares several assumptions with economic theory, it is novel in its treatment of costs and benefits. Most importantly, SET has a broad definition of benefits, which may include information, praise, prestige and other non-material rewards (see Blau 1964). This definition of benefits affects the nature of relationships in contrast to those where rewards are purely material. There are two consequences of such a definition of benefits. First, social exchange relationships tend to be flexible and, given that rewards are often non-material, are defined by processes far more subtle than formal bargaining (Stafford 2008). Second, a preponderance of non-material rewards and a lack of formal negotiation over the exchange of benefits leads to situations where benefits are offered in exchange for benefits in return, but these benefits are anticipated rather than guaranteed. SET therefore views relationships following formation as consisting of turns, and provides a useful framework for the analysis of relationship formation, maintenance and breakdown.

SET provides several advantages over the present tacit exchange framework for understanding intra-party relationships. Furthermore, the use of this distinctive exchange framework allows for several of Ware's criticisms of traditional exchange applications to be addressed (1992). This is because social exchange effectively captures several key aspects of such relationships. First, SET accounts for both extrinsic benefits with economic value (for example, information) as well as purely social benefits (for example, gossip) which maintain participation in relationships (see Blau 1964). In so doing, and in contrast to pure agency accounts, SET specifies the non-economic benefits that are crucial to the maintenance of relationships. This is particularly appropriate for the study of intra-party relationships because the material 
resources available to elites to reward activists in developed democracies has declined in markedly throughout the twentieth century (see, e.g., Panebianco 1988). Second, because SET recognises non-economic benefits, the mechanisms used to maintain reciprocation of benefits are more subtle than those used in relationships where economic benefits are exchanged. In particular, activists in relationships provide benefits in exchange for anticipated benefits, but they cannot be guaranteed that reciprocation will be forthcoming. The result is uncertainty, especially in the early stages of relationships (Whitener et al. 1998: 515). This is an ideal framework for the study of political parties, where the institutions structuring elite-activist relationships are often loose or even non-existent.

\section{Methods and Sources}

The findings presented in the following case study derive from 37 open-ended and later semi-structured interviews with Canadian MPs conducted between January and August 2010. These interviews were designed to explore the working relationships that exist between MPs and the activists of their constituency associations. In addition, I interviewed eight constituency association presidents in ridings with MPs I had interviewed and engaged in direct observation research by attending constituency association executive meetings when MPs were in attendance.

All MPs interviewed sat in the 40th parliament from 2008 to 2011. These MPs were selected in order to maximise variation across a number of factors including party, gender, tenure, region and constituency type. The resulting sample of MPs varied across all of these factors. Of the MPs interviewed, $57 \%$ sat in the Liberal caucus, while $27 \%$ and $16 \%$ were Conservative and New Democratic Party (NDP) MPs respectively. Of the MPs interviewed, $24 \%$ were women. Further, 30\% of the MPs were newly elected in the 2008 national election, whereas the remainder had served at least two terms. MPs from across the country were interviewed: $46 \%$ hailed from Ontario, 27\% from Atlantic Canada, 16\% from Western Canada and 8\% from Quebec. Finally, the MPs interviewed represented different types of ridings: $41 \%$ count as rural ridings and $59 \%$ as urban constituencies. While small-n research cannot produce representative results, this variation provides confidence in the findings presented below.

\section{Case Study: Canadian Members of Parliament and Party Activists}

In delineating the benefits offered by actors in relationships, it is crucial to first specify the overall institutional context within which these relationships take place, as this may affect the distribution of resources in a range of ways, and, second, determine their positions and consequently the resources at their disposal to offer as benefits.

Canadian parties are typically understood as cadre organisations dominated by the party in public office (essentially the leader) on one hand and the local constituency associations on the other (see Carty 2002). This balance between the two faces of the parties is maintained through an ancient allocation of powers: leaders are provided with the power to develop policy and speak on behalf of the party whereas members in the constituency associations select personnel through local nomination contests and are left free to conduct their own affairs (Carty and Cross 2006: 97-8). This allocation is not guaranteed, and both leaders and members have occasionally impinged on the traditional rights of one another (e.g., Koop and Bittner 2011; Young and Cross 2002). Nevertheless, this distribution of powers has important consequences for party members and activists, namely that ideological or policy benefits 
are difficult to attain within a party organisational structure that allows leaders to chart their own policy courses through the use of polls and focus groups rather than consultation with party members. Indeed, in their survey of Canadian party members, Cross and Young (2002: 563) found that members of the major parties were more likely to be motivated to join in order to support candidates rather than create policy. This division of the party organisation, and the ghettoisation of activists into their local constituency associations, means members come to rely on their MPs for a range of rewards for their participation, and MPs are empowered as a result.

The constituency associations themselves consist of three components: (1) the wider party membership in the constituency; (2) the small executive that is elected by party activists at Annual General Meetings; and (3) the smaller number of officers (including the president, vice-president, etc.). Crucially, constituency executives are tasked with organising nomination races to decide on local party candidates. Executive members also take on additional duties on committees dedicated to fundraising, policy formulation, election preparedness and events planning. Executives are typically small cadres that take responsibility for most representational and electoral tasks that benefit incumbent MPs, and conduct business during executive meetings where the MP is often in attendance (Koop 2010).

Where then does this leave Canadian MPs? While MPs are required to engage in legislative work in parliament, the nature of their party organisations demands that they keep their eyes trained homeward. Tending to the local activist base in the constituency association is crucial for MPs as it is these activists who provide inter-election support, organise and vote in renomination contests, and work during re-election campaigns.

In the ridings, MPs are similar to volunteer managers: unpaid volunteers staff their constituency associations and they have few if any material benefits to provide. However, MPs occupy positions that allow them to provide a range of non-material benefits to the constituency activists with whom they share relationships. There are two aspects to these positions, both captured by Carty's account of their dualism (Carty 2002). First, MPs are party intermediaries: they occupy an intermediary position between the party in public office and the party on the ground. Second, MPs are local elites: they occupy positions with certain influence and status in their constituencies. In providing benefits deriving from their positions to local activists, MPs (1) enhance the solidary and ideological goals that activists often seek by participating in parties and (2) reciprocate activists' local incumbent support efforts with benefits which help to maintain the relationship between MPs and constituency activists.

Table 1 summarises the specific benefits that flow from MPs' positions as both party intermediaries and local elites.

As party intermediaries that simultaneously occupy both the party in public office and the party on the ground, MPs are able to provide local activists with information from the centre of the party, provide access to the centre of the party, and allow local activists to

Table 1

Benefits provided by MPs to constituency party members

\begin{tabular}{lll}
\hline & & \multicolumn{2}{c}{ MP positions } \\
Bens as party intermediaries & MPs as local elites \\
Information from the centre & $\begin{array}{l}\text { Access to the centre } \\
\text { Speaking to the centre }\end{array}$ & Enhancing local sociability \\
& &
\end{tabular}


speak to the centre of the party. As local elites, MPs are able to enhance the sociability of local party activities and enhance the local status of activists. Crucially, these benefits are nonmaterial in nature. The following subsections are organised first by the positions that enable MPs to provide benefits to activists, and second by the specific benefits provided.

\section{MPS as Party Intermediaries}

Party activists staff the party on the ground but are necessarily separated from the party in public office. MPs, however, can act as conduits between local activists and the centre of the party given their intermediary position between the party on the ground and the party in public office. Many MPs are aware that acting as intermediaries between the periphery and the centre enhances the solidary and ideological rewards that activists receive from their participation, and so commit time and effort to doing so. MPs draw on their positions as party intermediaries to provide rewards to activists in three ways: MPs provide information from the party centre, provide access to the centre, and assist activists in speaking to the centre.

Selle and Svasand (1983: 215-16) note that 'the [local] political party organization used to be an important means to distribute information from leaders to followers', but that advancements in information technology that aided the party transitions into electoral-professional forms allowed leaders to speak to activists along with all other citizens. Nevertheless, observation of Canadian constituency association meetings reveals that activists still receive special privileged information from the party leadership, via the intermediary MP who rewards local activists by providing them with information from the centre.

The first type of information that MPs provide relates to the party's legislative activities in Ottawa. MPs discuss the party's legislative initiatives, how the party is approaching ongoing or upcoming issues, and strategic issues. MPs refer to discussion from party caucus meetings despite caucus confidentiality, providing activists with the impression that they are receiving privileged information that is not widely available. MPs also recount first-hand stories of legislative politics, providing an insider perspective to accounts that activists follow in media reports. Activists who have followed these media accounts closely often take advantage of the opportunity to request MPs' side of the story.

One MP recounts how he uses executive meetings to keep members well informed of what is taking place in Ottawa:

I try to keep them really well informed on what we're doing. You know, legislation that's in the works or that's in the public eye. Things that I'm doing, if there's controversial issues (generally there's always something controversial) then I try to give them the facts as I appreciate them. So just keeping them involved. Making them feel like, 'Hey! I'm getting some information that not everybody gets'. It makes them feel involved. It makes them feel a bit special that they're getting information from parliament through me, from the prime minister through me, that the average citizen out there isn't getting. So that motivates them to a certain extent to be involved.

The second type of information provided to activists relates to the work of MPs as individuals. MPs report on a range of parliamentary activities, including their work on parliamentary committees, asking questions during Question Period, and introducing private activists' legislation. This information allows MPs to trumpet their own accomplishments as well as provide activists with the impression that their MP is hard-working and is making a name for him or herself in the capital. 
MPs also report on their work away from the capital. MPs report on their travels outside of the country on parliamentary business. In addition, constituency associations often call on MPs from outside the constituency to deliver speeches or headline local fundraisers or other events. If they have been in other constituencies to do so, MPs report back to their own executives on the success of these activities on behalf of the party. MPs also report back on local party organisations in other constituencies, including their strengths, weaknesses and the key personalities involved.

The third type of information that MPs report to their executives relates to discussion and gossip about other politicians and what takes place away from official business in the capital. Executive activists are typically curious about public figures that they see in the news and view their MP as someone who can report on these figures. MPs report on informal meetings with other MPs; compliment MPs from their own and other caucuses (for example, for being hard-working or effective in Question Period); criticise MPs (for example, for being abrasive); and pass on informal news that is not in the public domain. In these ways, MPs personalise their experiences in Ottawa, providing activists with information and insider gossip that is not available to other citizens.

Providing information from the centre enhances the solidary and ideological rewards that activists receive. An important aspect of solidary incentives relates to the feeling of being a 'part of a team'. While activists feel included in the constituencies where they participate in campaigns and association work, they often feel isolated from the wider party. MPs remedy this by providing information, news and gossip from outside the constituency. By doing so, MPs seek to demonstrate to these activists that they are members of a team that exists beyond the local association. One MP describes how they explicitly target solidary activists by providing information from the centre:

I give really detailed reports about what's going on in Ottawa and I find that people really, really appreciate that. They want to know what's going on, they want to be a part of something... That sort of feeling of inclusion is really important, that feeling of being a part of something ... people I think are there to ... be a part of something that's bigger than them.

Providing information also rewards activists with ideological motivations to participation. Activists that pursue ideological goals through their participation in parties with catch-all tendencies often feel that their work in the constituency on behalf of MPs does not translate into substantive policy outcomes at the national level. However, by providing information on the legislative activities of the party, MPs can demonstrate to these activists that the party is in fact pursuing the policy goals of the party.

MPs also reward activists for their participation by using their positions as party intermediaries to link local activists to elites in the parties, particularly other MPs. In providing access to the centre, MPs provide rewards to solidary activists in their associations.

MPs provide access to party elites by inviting elites to come to their constituencies and interact with local activists. These invitations are either formal or informal. First, MPs often attempt to recruit other MPs to their local functions, particularly annual general meetings and fundraisers, as guest speakers. Second, MPs introduce elites to executive members in informal ways. When elites visit the constituencies, MPs reward local activists by making time for them to meet and interact with elites. MPs also connect local activists to elites while in Ottawa.

In introducing activists to other MPs and party elites, MPs are guided by local preferences. During executive meetings, activists request personal accounts of, and gossip concerning, other MPs in the party. MPs use this information to determine who to introduce local 
activists to. What this suggests is that MPs know that connecting local activists to elites is an effective method of rewarding their participation, and so they gather input on which elites local activists are most interested in meeting in order to maximise the benefit of their efforts.

Providing a means for local activists to meet and interact with party elites provides solidary rewards to activists. In addition, by linking these activists to figures from outside the party, MPs enhance these activists' feelings that they are a part of a team that exists outside the boundaries of their own constituencies, and that they have access to important figures in the party.

MPs also reward activists for their participation by supporting and encouraging local policy formulation processes that are subsequently debated at party policy conventions. MPs reward activists by assisting them in speaking to the centre. By doing so, MPs assist local activists in speaking to the centres of their parties. All three major Canadian parties have policy formulation processes that originate with local policy resolutions and culminate in non-binding votes at party-wide policy conventions. While participating in these processes is not attractive to all activists, doing so is attractive to activists with ideological motivations to continued participation. MPs can therefore reward activists by supporting local policy formulation processes.

MPs retain participation through policy formulation processes in two ways. First, they encourage constituency associations to develop mechanisms for policy development. As the first step to doing so, MPs encourage activists to take on the role of policy chair. Policy chairs are executive activists who take responsibility for local policy formulation processes and the development of resolutions to submit to party conferences for debate. Second, once a policy chair and committee has been created, MPs take these processes seriously and encourage local activists to participate in them. This takes several forms. In some cases, MPs themselves participate in local processes, corresponding with the policy chair about local resolutions. Most importantly, MPs spoke out in favour of activists' resolutions at party conventions. In doing so, MPs validate the policy work of local ideological activists and assist them in speaking to the centre of the party.

Party activists participate in these formal policy formulation processes, but they also engage in policy work indirectly by presenting their views to MPs during executive meetings. At these meetings, MPs typically ask activists for feedback on the party's performance and policy ideas. In response, executive activists present ideas for new policies or recommendations to amend existing policies. The crucial point is that MPs, by demonstrating to ideological activists that they take local policy input and local policy formulation processes seriously, can provide a substantial reward to those ideological activists and encourages their continued participation in the constituency party.

\section{MPs as Local Elites}

MPs are important figures in their communities, particularly given their abilities to address constituents' needs and problems through their service functions. MPs may even be seen as celebrities in some communities, and are regularly deluged with invitations to attend local functions and events (Docherty 1997: 175). MPs exploit their status as local elites to enhance the rewards that local party activists receive from their participation. MPs draw on their positions as local elites to rewards activists in two ways: by contributing to (1) the sociability of local party business and (2) the local status of activists within their own communities. 
A crucial benefit offered by MPs to activists in their constituency associations relates to the social aspect of local party organisations. On the one hand, the salience of social incentives to continued participation has declined as mass parties - formerly excellent locations for solidary interactions - have adopted catch-all orientations (Dalton et al. 1984). On the other hand, the potential for social interactions within the context of geographically defined constituencies is increased as activists are provided with opportunities to develop and retain relationships with partisans who reside within their communities. Young and Cross (2004: 567) find in their survey of Canadian party members that solidary incentives are particularly important to motivating members to continue participation in their parties. MPs with knowledge of their constituency associations recognise the potential usefulness of social incentives for the retention of activists' participation and accordingly work to enhance their efficacy. Indeed, Carty (1991: 60) notes that constituency associations with incumbent MPs tend to have far more inter-election maintenance events than associations without an MP.

MPs enhance the efficacy of local events first by adding personal social elements to regular party business; they enhance local sociability. The inter-election business of constituency associations consists for the most part of holding meetings, planning events and fundraisers, and maintaining local membership bases; this is often mundane administrative work. MPs can aid in activists' participation by adding social elements to this business. For example, MPs tend to be a positive, sociable presence at these meetings. They can be expected to wander, talk, and insert jokes and good-natured jabs into the proceedings of the meetings. The result is that activists, particularly those motivated primarily by solidary goals, have an added incentive to attend executive meetings if they know in advance that the MP will be in attendance.

It is standard practice for activists to conclude executive meetings with informal social gatherings. MPs, by their mere presence at executive meetings and the subsequent social gatherings, make these gatherings more attractive to activists. Just as MPs attract activists to executive meetings, so too do they attract activists to sociable follow-ups. This is particularly true-and rewarding - for solidary activists.

MPs also contribute to the sociability of constituency party life by organising events that are designed to reward local activists. Most MPs host two events a year to thank local activists for their work, typically falling during the Christmas and summer holidays. These events are sometimes open to the local membership as a whole or even to citizens in general. But they are rarely advertised in such a manner, as their implicit purpose is to thank constituency activists for their service and to express the MP's gratitude. These events also provide opportunities for local activists to socialise and interact with the MP in an informal setting; indeed, these events are often held at MPs' homes for that reason.

What these examples illustrate is that many MPs are aware of the importance of sociability to retaining the participation of many activists, and they make personal, strategic efforts to enhance this benefit for local activists. These efforts therefore primarily benefit activists with solidary motivations to continued participation. When activists participate in constituency associations for solidary reasons, their efforts are rewarded by MPs who enhance the sociable rewards of that activism.

MPs also use their positions as local elites to reward activists by enhancing the local status of those activists. Activists that sit on constituency association executives often develop reputations as local figures that have the ear of the MP. The result is that constituents come to see these activists as conduits to the MP, with the prestige that comes with this recognition. MPs are aware of this dynamic, and so reward activists by enhancing the local status of these activists. 
MPs enhance the local status of activists by including them in the representative process. MPs often rely on executive activists to keep them abreast of service and allocative requirements in their communities and to alert them if requirements have arisen. In this capacity, activists come to be seen as emissaries of the MP in their communities, and citizens seek out these activists to express service or allocative requirements. 'They see their job as being the eyes and the ears of the MP and the MP's office', notes one MP of his executive activists. 'They like that because it gives them a little prestige at the local card club or the dart club.'

Activists may also come to be seen as local figures able to persuade MPs to attend local events. When this occurs, activists are inevitably in attendance in order to reap the status rewards of their affiliation with the MP. Indeed, one MP reported that he attends an event almost every weekend to which local activists have invited him. The status rewards of recruiting and accompanying the MP to the community event are substantial for activists.

\section{Conclusion}

This inquiry takes a crucial first step in the application of SET to intra-party relationships, with a single case study. This research about the nature of intra-party relationships, however, raises many questions for future research about the variability of the relationships explored. Do representatives differ in the rewards provided to local activists and, if so, what might help explain such variation? Differences may be observed between government and opposition MPs as well as between different contextual settings, in particular between urban and rural constituencies. Perceived safety may also exercise an influence on the behaviours of MPs, with MPs unsure of their re-election fortunes likely to offer more rewards to local activists.

\section{NOTES}

1. For two early examples of such an approach, see Wright (1971) and Schlesinger (1975).

\section{REFERENCES}

BILLE, LARS. 2001. Democratizing a democratic procedure: myth or reality? Candidate selection in Western European parties, 1960-1990. Party Politics 7 (3): 363-80.

BLAU, PETER. 1964. Exchange and Power in Social Life. New York: Wiley.

CARTY, R. K. 1991. Canadian Political Parties in the Constituencies. Toronto: Dundurn Press.

CARTY, R. K. 2002. The Politics of Tecumseh Corners: Canadian political parties as franchise organizations. Canadian Journal of Political Science 35 (4): 723-45.

CARTY, R. K. 2004. Parties as franchise systems: the stratarchical organizational imperative. Party Politics 10 (1): 5-24.

CARTY, R. K. and WILLIAM CROSS. 2006. Can stratarchically organized parties be democratic? The Canadian case. Journal of Elections, Public Opinion, and Parties 26 (2): 93-114.

CARTY, R. K. and munRoe EAgles. 2005. Politics is Local: National Politics at the Grassroots. Oxford: Oxford University Press.

CLARK, ALISTAIR. 2004. The continued relevance of local parties in representative democracies. Politics 24 (1): 35-45.

CLARK, PETER B. and JAMES Q. WILSON. 1961. Incentive systems: a theory of organizations. Administrative Science Quarterly 6 (2): 129-66. 
CROSS, WILLIAM and LISA YOUNG. 2002. Incentives to membership in Canadian political parties. Political Research Quarterly 55 (3): 547-70.

DALton, Russell J., scott C. Flanagan and Paul Allen beCk. (eds) 1984. Electoral Change in Advanced Industrial Democracies: Realignment or Dealignment? Princeton, NJ: Princeton University Press. DENVER, DAVID, GORDON HANDS, JUSTIN FISHER and IAIN MACALLISTER. 2002. The impact of constituency campaigning in the 2001 general election. British Elections Parties Review 52 (2): 89-94.

DOCHERTY, DAVID C. 1997. Mr. Smith Goes to Ottawa: Life in the House of Commons. Vancouver: UBC Press.

KATZ, RICHARD S. and PETER MAIR. 1995. Changing models of party organization and party democracy: the emergence of the cartel party. Party Politics 1 (1): 5-28.

KOelble, THOMAS A. 1996. Economic theories of organizations and the politics of institutional design in political parties. Party Politics 2 (2): 251-63.

KOOP, ROYCE. 2010. Professionalism, sociability, and the Liberal Party in the constituencies. Canadian Journal of Political Science 43 (4): 893-913.

KOOP, ROYCE and AMANDA BITTNER. 2011. Parachuted into parliament: candidate nomination, appointed candidates, and legislative roles in Canada. Journal of Elections, Public Opinion, and Parties 21 (4): $431-52$.

MAY, JOHN D. 1973. Opinion structure of political parties: the special law of curvilinear disparity. Political Studies 21 (2): 135-51.

MULLeR, WOLFGANG C. 2000. Political parties in parliamentary democracies: making delegation and accountability work. European Journal of Political Research 37 (3): 309-33.

Panebianco, Angelo. 1988. Political Parties: Organization and Power. Cambridge: Cambridge University Press.

QUINN, THOMAS. 2002. Block voting in the Labour Party: a political exchange model. Party Politics 8 (2): 207-26.

QUINN, THOMAS. 2010. New Labour and the trade unions in Britain. Journal of Elections, Public Opinion, and Parties 20 (3): 357-80.

QUINN, THOMAS. 2012. Spin doctors and political news management: a rational choice 'exchange' analysis. British Politics 7: 272-300.

SCARROW, SUSAN E. 1996. Parties and Their Members: Organising for Victory in Britain and Germany. Oxford: Oxford University Press.

SCHLESINGER, JOSEPH A. 1975. The primary goals of political parties: a clarification of positive theory. American Political Science Review 69 (3): 840-9.

SELLE, PER and LARS SVASAND. 1983. The local party organization and its members: between randomness and rationality. Scandinavian Political Studies 6 (3): 211-29.

SEYD, PATRICK and PAUL WHITELEY. 1992. Labour's Grass Roots: The Politics of Party Membership. Oxford: Clarendon Press.

STAFFORD, LAURA. 2008. Social exchange theories. In Engaging Theories in Interpersonal Communication, edited by Leslie A. Baxter and Dawn O. Braithwaite. New York: Sage, pp. 377-89.

STROM, KAARE. 1990. A behavioural theory of competitive political parties. American Political Science Review 34 (2): 565-98.

WARE, ALAN. 1992. Activist-leader relations and the structure of political parties: 'exchange' models and vote-seeking behaviour in parties. British Journal of Political Science 22 (1): 71-92.

WHITENER, ELLEN M., SUSAN E. BRODT, M. AUDREY KORSGAARD and JON. M. WERNER. 1998. Managers as initiators of trust. The Academy of Management Review 23 (3): 513-30.

WIDFELDT, ANDERS. 1999. Linking Parties with People? Party Membership in Sweden, 1960-1997. London: Ashgate. 
WRIGHT, WILLIAM E. 1971. Comparative party models: rational-efficient and party democracy. In A Comparative Study of Party Organization, edited by William E. Wright. Columbus: Charles E. Merrill, pp. 17-54.

YOUNG, LISA and WILLIAM CROSS. 2002. The rise of Plebiscitary Democracy in Canadian political parties. Party Politics 8 (6): 673-99.

YOUNG, LISA and WILLIAM CROSS. 2004. The contours of political party membership in Canada. Party Politics 10 (4): 427-44.

Royce Koop is Assistant Professor in the Department of Political Studies at the University of Manitoba in Winnipeg, Manitoba, Canada. He is the author of Grassroots Liberals: Organizing for Local and National Politics (UBC Press, 2012) and co-editor of Parties, Elections and the Future of Canadian Politics (UBC Press, 2013). Email: Royce.Koop@umanitoba.ca 